\title{
CORRECTION
}

Open Access

\section{Correction to: Beyond race?}

Sawitri Saharso ${ }^{1}$ (1) and Tabea Scharrer S, $^{*}$ (i)

The original article can be found online at https://doi. org/10.1186/s40878-021$00272-y$.

${ }^{*}$ Correspondence: scharrer@eth.mpg.de

${ }^{2}$ MPI for Social Anthropology, Halle, Germany

Full list of author information is available at the end of the article

\section{Correction to: Saharso and Scharrer Comparative Migration Studies (2022) 10:4 https://doi.org/10.1186/s40878-021-00272-y}

Following publication of the original article (Saharso \& Scharrer, 2022), the authors would like to correct a reference and a typo in the article text.

- "Meissner, F., \& Steven, V. (2015)", should be "Meissner F. \& Vertovec, S. (2015)";

- In pag. 10 the word tran-sracial should be "transracial".

The original article (Saharso \& Scharrer, 2022) has been corrected.

\section{Author details}

${ }^{1}$ Department of Sociology, VU Amsterdam, Amsterdam, The Netherlands. ${ }^{2}$ MPI for Social Anthropology, Halle, Germany ${ }^{3}$ University of Bayreuth, Bayreuth, Germany.

Published online: 31 January 2022

Reference

Saharso, S., \& Scharrer, T. (2022). Beyond race? Comparative Migration Studies, 10, 4. https://doi.org/10.1186/ s40878-021-00272-y

\section{Publisher's Note}

Springer Nature remains neutral with regard to jurisdictional claims in published maps and institutional affiliations. author(s) and the source, provide a link to the Creative Commons licence, and indicate if changes were made. The images or other third party material in this article are included in the article's Creative Commons licence, unless indicated otherwise in a credit line to the material. If material is not included in the article's Creative Commons licence and your intended use is not permitted by statutory regulation or exceeds the permitted use, you will need to obtain permission directly from the copyright holder. To view a copy of this licence, visit http:// creativecommons.org/licenses/by/4.0/. 